\title{
How is the Attitude of Japanese Millennials Towards Indonesian Rattan Furniture?
}

\author{
Komang Yudhi Kamala ${ }^{1,}$ Christina Rahardja ${ }^{2, *}$ Aluisius Henry Pratono ${ }^{3}$ \\ ${ }^{1}$ University of Surabaya, Surabaya, Indonesia \\ ${ }^{2}$ University of Surabaya, Surabaya, Indonesia \\ ${ }^{3}$ University of Surabaya, Surabaya, Indonesia \\ *Corresponding author. Email: christina_r@staff.ubaya.ac.id
}

\begin{abstract}
Recently, environment and ecology have become critical issues for the global population and entrepreneurs. The millennial generation is considered one of the most prominent population groups and an attractive target for many companies to engage. This study aims to understand the Japanese millennials' attitude toward Indonesian rattan furniture as a green product. Indonesia is one of the biggest rattan furniture suppliers to the global market where Japan is listed as the third biggest market for Indonesian rattan furniture after the U.S. and European region. In this study, the researchers made an exploratory qualitative approach to understand Japanese millennials' attitude towards Indonesian rattan furniture by analyzing the data based on the theory of characteristics of millennials and consumer attitude. This research was conducted in Indonesia and Japan. The results show Japanese millennials' attitude toward Indonesian rattan furniture is positive. Aesthetic values, price, and "summer" image of rattan furniture are the findings.
\end{abstract}

Keywords: Japanese millennials, attitude, values, and Indonesian rattan furniture.

\section{INTRODUCTION}

Environment and ecology have become critical issues for the global population and entrepreneurs (Allen \& Malin 2008). People are becoming more aware of the environmental impacts of human activities and make changes in daily behavior regarding this issue (Wong 2012). Many companies are trying to find and develop new ideas and plan a strategy to position their green brand in the customer's mindset to compete in the market (Suki 2016). Eco-innovation and green purchasing are two main important things for sustainable development (Joshi and Rahman 2016). The focus of ecoinnovation is to assimilate the sustainability environment at a product when producing goods or services (Veleva \& Ellenbecker
2001). Green purchasing behavior means an ethical decision-making behavior and it is being recognized as socially responsible behavior (Joshi \& Rahman 2016). Apart from the increase of environmental awareness by the majority of society, one question is pointing to the young generation or the millennial generation. Will the increase of environmental awareness in the major society make the millennial generation willing to buy and consume more green products in their daily lives? The motive of this question is because there are still a few academic researchers that examine millennial generation consumption toward green products ( $\mathrm{Lu}$ et al. 2013).

One important reason why the research is essential because presently millennial generation that was born between the 80s-90s of 
the twentieth century (Stanimir 2015) is one of the most prominent groups of the popultion, and their purchasing power made them become an interesting target for many industries (Moreno et al. 2017).

This research will focus on Japanese millennials as the subject. Aiming to determine the Japanese millennials attitude towards Indonesian rattan furniture, this research will analyze the findings based on consumer ttitude theory by Steenkamp \& de Jong (2010) that consists of multiple levels and types of values. Therefore, companies should focus more on creating a product that could attract young consumers (Millennials) based not only on the economic value but also on the economic value. In general, the millennial generation prefers a brand based on values expressing their individuality (Knight \& Kim 2007). In this study, the researcher chose Indonesian furniture made from rattan as our green product object. The reason for choosing this item as the object is because furniture made of rattan cane is modern and environmentally safe (Amoah et al. 2015).

The previous study conducted in Indonesia found that rattan cane harvesting does not conflict with forest conservation objectives because it has little effect on the forest structure and diversity (Widayati \& Carlisle 2012). Rattan industry is worth billiondollar, where Indonesia is the world's biggest rattan exporter in the world. In 2012, $43 \%$ of the rattan furniture imports were coming from Indonesia (Myers 2015). In addition, Japan is the third biggest rattan furniture importer after the United States of America and the European Union. According to data from the Ministry of Trade Indonesia (2016), it was noted that Japan imports rattan furniture worth US\$22,54 million. Japan is one of the biggest markets for rattan furniture from Indonesia. According to the Ministry of Trade of The Republic of Indonesia, Japan is the second favorable target export country for rattan furniture from Indonesia in 2015. (Ministry of Trade of The Republic of Indonesia, 2016). Then it is essential to explore the Japanese millennials' attitude toward green products and specifi- cally towards Indonesian rattan furniture. Because, as the market leader of the rattan furniture exporter to Japan, it is important to explore the Japanese millennial generation's attitude toward Indonesian rattan furniture.

\subsection{Research Purposes}

This study aims to provide further insight into the Japanese Millennials' attitude toward green products, specifically to Rattan Furniture from Indonesia. Therefore, this study will focus to explore the consumers' attitude of Japanese millennials towards Indonesian rattan furniture. The research question is as follows:

RQ. How is Japanese Millennials' attitude toward Indonesian Rattan Furniture as a green product?

A previous empirical study in electronic devices indicates that green technology fails to promote awareness of green consumption behavior (Bekaroo et al. 2018). The costbenefit analysis on green consumption may justify whether a company needs to get involved in promoting green awareness (Pratono et al. 2017). Hence, future studies need to explore the intention-behavior gap of green consumption among the millennial generation (Al Mamun et al. 2018).

\section{RESEARCH METHODS}

This research method is exploratory research in a qualitative approach where the informants are the Japanese millennial generation. The researcher will explore and dig deeper information on how the Japanese millennials' attitude toward Indonesian rattan furniture is. Exploration qualitative design is flexible, data-driven, and context-sensitive that can plug gaps in knowledge. This research relies on an interpretive approach. The interpretive approach sees people as the primary source of data, along with people's interpretations, perceptions, meaning, and understanding (Mason 2002).

The research time was conducted during the university project between the University 
of Surabaya and Tokai University. This study was conducted in two countries of Indonesia and Japan. In Indonesia, the research was conducted in Surabaya city. In Japan, the research was conducted in several locations, namely Kanagawa city (Tokai University), Shibuya district (Tokyo), Shinjuku district (Tokyo), and Akibahara district (Tokyo). Researchers did a company visit in Mojosari at one of the rattan company producers to observe and dig more information about the rattan furniture industry. This research was conducted by observing and interviewing all the chosen Japanese millennials informants in English. Researchers observed when students and professors from Tokai University came to Surabaya, and the researcher observed informants' behavior of consuming products, observing their attitude and curiosity during the presentation session about Indonesian rattan furniture in front of twenty Japanese students and three professors from Tokai University. Two lecturers from the University of Surabaya participated in this project. The observation was also conducted in Japan; the researchers want to understand the characteristics, behavior, and lifestyle of Japanese millennials in several places mentioned above.

The interview activities were conducted in English to bridge the language barrier between researchers and informants. The interview protocol applied a semi-structured method containing open-ended questions. Informants are free to state and answer based on informants' personal perceptions, experiences, and opinions. A detail of informants is exhibited in Table 1 below. In purpose to minimize bias in this study, the triangulation method was applied in this research. This method is necessary to seek the corroborate one source and with another (Mason 2002). Triangulation refers to the use of a combination of methods to explore a set of research questions.

The researcher will cross-validate all data collecting methods interview transcript, observation notes, and other documents from articles, news, journal and experts confirmation to seek the consistency of the data.
Table 1. Informants

\begin{tabular}{|c|c|c|c|c|c|}
\hline No & $\begin{array}{l}\text { Informants } \\
\text { (Age) }\end{array}$ & $\begin{array}{l}\text { Informant's } \\
\text { Status }\end{array}$ & $\begin{array}{l}\text { Duration } \\
\text { Minutes }\end{array}$ & $\begin{array}{l}\text { No. of Ses- } \\
\text { sion }\end{array}$ & Nationality \\
\hline 1 & Taihei (20) & $\begin{array}{l}\text { Student of } \\
\text { TokaiUniver- } \\
\text { sity }\end{array}$ & 40 & 1 & Japan \\
\hline 2 & Kenjiro (21) & $\begin{array}{l}\text { Student of } \\
\text { TokaiUniver- } \\
\text { sity }\end{array}$ & 27 & 1 & Japan \\
\hline 3 & Michiko (20) & $\begin{array}{l}\text { Student of } \\
\text { University of } \\
\text { Surabaya }\end{array}$ & 19 & 1 & Japan \\
\hline 4 & Chico (19) & $\begin{array}{l}\text { Student of } \\
\text { TokaiUniver- } \\
\text { sity }\end{array}$ & 41 & 1 & Japan \\
\hline 5 & Ranko (21) & $\begin{array}{l}\text { Student of } \\
\text { Shih Chien } \\
\text { University }\end{array}$ & 45 & 1 & Japan \\
\hline Total 1 & Interview Time & & \multicolumn{3}{|c|}{172 minutes } \\
\hline
\end{tabular}

Source: Data of Interview

There are three experts two Professors from Tokai University Japan and one Senior Researcher from the University of Surabaya.

\section{RESULTS AND DISCUSSIONS}

The researchers discuss the research findings and evidence based on the theories used for this study, and divided them into three parts providing deeper understanding of the characteristics of Japanese millennials, findings on Japanese knowledge and preferences on Indonesian rattan furniture as one of the green products, and the findings of Japanese millennials attitude towards Indonesian rattan furniture based on the values theory.

First, the researcher has made observations in both in Indonesia and several places in Japan to provide a deeper understanding of the characteristics of Japanese millennials, for specific purposes such as going to work, shopping, and even just for using public transportation (bus, train, MRT station, and train station). To support the evidence of the characteristics of the Japanese millennials, the researchers also cited several statements from the informants and using secondary sources of information from experts' confirmation and credible articles that will support the findings of the data. 
Japanese millennials possess a close relationship with high technology products in daily life. Japanese millennials are familiar with applying advanced digital technology ranging from home appliances, toilets, transportation, restaurant services, and multi-payment in Japan. These are some of the statements from informants: "I think Japanese people prefer a smart product that makes you looks 'smart' like a business person I think" - Ranko. "I have an EV (electric vehicle) car in my house (I use the EV car) every day when I go to school" - Kenjiro.

The findings in this research found that Japanese millennials characteristics only match two out of five characteristics according to the theory from (Syrett \& Lammiman 2004). The two characteristics found in this study for Japanese millennials are intimacy (close relationship with high-technology products) and awareness (social responsibility). The Japanese millennials attitude of discipline, politeness, and the concern for the surrounding environment as their awareness.

Second, the researcher will show the findings of several things related to the relationship of Japanese millennials with Indonesian rattan furniture, such as knowledge about green products and rattan products and preferences on Indonesian rattan furniture. Japan is famous for high-technology products and low-emission transportations; for example, there are many electric vehicles and hybrid cars with lower gas emissions than ordinary vehicles that use fossil fuels. The most common electric and hybrid vehicles are Nissan Leaf and Toyota Prius. There was one interesting point found during the interview session and observation in Japan. Even though the utilization and usage of green products such as electric and hybrid vehicles are widespread for Japanese millennials, the knowledge of green products' meaning, and benefits is still lacking. Some of the informants mentioned that sometimes they could not distinguish between regular and green products. "I have no idea. Because people in Japan to buy product, (whether) this is a green product or not, people don't care about it" - Taihei. "I did not know much about rattan product or furniture and I searched about it after your presentation" - Kenjiro.

According to the data from the Ministry of Trade of Republic Indonesia in 2016, Japan is the second-largest country after the United States of America (USA) which is the target of the Indonesian market for rattan furniture (Ministry of Trade of The Republic of Indonesia 2016). One of the concerns is that even though Japan is a big market for Indonesian rattan furniture, rattan furniture product is still not popular to some Japanese millennials, Three out of five informants had never seen, bought, or experienced any rattan product. Only two informants have rattan products such as bags and chairs.

Third, in this part, to determine the Japanese millennials attitude toward Indonesian rattan furniture, the researchers concentrate on two levels of values which are General and Consumer domain-specific to be more specific. The collected data were taken according to each value type in both value levels.

In terms of general values, the researcher took three out of ten value types hedonism, self-direction; and universalism to be analyzed. To highlight the findings, table 2 presents facts in the research field related to the theory use.

Table 2. Interpretation of General Values Theory and Findings on Attitude TowardIndonesian Rattan Furniture

\begin{tabular}{lll}
\hline Value Type & \multicolumn{1}{c}{ Definitions } & \multicolumn{1}{c}{ Findings } \\
\hline Hedonism & $\begin{array}{l}\text { Personal pleasure and sen- } \\
\text { suous gratification }\end{array}$ & $\begin{array}{l}\text { "Summer" image and Aes- } \\
\text { thetic value of Indonesian } \\
\text { rattan furniture as a person- } \\
\text { al pleasure }\end{array}$ \\
Self-direction & $\begin{array}{l}\text { Autonomous thinking } \\
\text { and choice of action, cre- } \\
\text { ation, exploration }\end{array}$ & $\begin{array}{l}\text { The curiosity and willing- } \\
\text { ness to try new and different } \\
\text { products including Indone- } \\
\text { sian rattanfurniture }\end{array}$ \\
& & \\
Universalism & $\begin{array}{l}\text { The possession of broad- } \\
\text { minded in termof cosuming } \\
\text { global products that benefit } \\
\text { both consumer andnature }\end{array}$ & $\begin{array}{l}\text { Japanese millennials accept } \\
\text { Indonesian rattanfurniture as }\end{array}$ \\
& $\begin{array}{l}\text { a global product which sup- } \\
\text { port } \\
\text { sustainability environment }\end{array}$
\end{tabular}

Source: edited by authors 
The "Summer Image" brings pleasure to Japanese millennials. "I think I like the design of rattan furniture and also even its winter time in Japan, I feel like in the summer or Bali, so it brings like another atmosphere." Chico. For Japanese millennials, Indonesian rattan furniture is a new thing, and the design and quality of the Indonesian rattan furniture are taking a significant role in influencing Japanese millennials' attitudes. The design of Indonesian rattan furniture is attractive for Japanese millennials because it has an aesthetic design with small size and lightweight, making the furniture easier to be arranged in the house interior. In this case, Indonesian rattan furniture possesses a good image (good quality) in the Japanese market and Japanese millennials, but the price of rattan is the obstacle; it would be much better if rattan furniture could be lower than the current price.

According to the data from the Ministry of Trade of the Republic of Indonesia, the reputation of Indonesian rattan furniture is outstanding in the Japanese market with $61.2 \%$ of the total market share for exporters of rattan products to Japan in 2015 (Ministry of Trade of The Republic of Indonesia, 2016). Furthermore, after Japanese millennials knew that Indonesian rattan furniture is also a part of green products that support sustainability, they have a very positive image and attitude toward Indonesian rattan furniture. In terms of consumer domain-specific values, there are five types of values, which are materialism, consumer innovativeness, nostalgia, consumer ethnocentrism, and environmentalism. This is the beginning indication where Japanese millennials are possessing materialism. This is the beginning indication where Japanese millennials are possessing materialism. "The fashion or cosmetics brand, so I think I need to get the trend like them. And also, I really like to get information and read about cosmetics to be looks cuter" - Chico. Japanese millennials know details about Indonesian rattan furniture will increase their desire to buy in the future. "if I live by my-self, I will get more space than now, I want to buy (rattan furni- ture). Because, I understand the deforestation in Indonesia and I want to solve this problem" - Taihei. For Japanese millennials, the environmental benefit of the Indonesian rattan furniture is interesting information and attracts Japanese millennials to buy the product in the future. "Hmm, I think it's important to think about the environment because I've changed my mindset when I started to learn about it" - Kenjiro. Table 3 aims to provide highlights and brief explanation.

Table 3. Interpretation between Consumer DomainSpecific Values Theory andFindings on Attitude Toward Indonesian Rattan Furniture

\begin{tabular}{|c|c|c|}
\hline $\begin{array}{l}\text { Value } \\
\text { Type }\end{array}$ & Definition & Findings \\
\hline Materialism & $\begin{array}{l}\text { A central conviction of theim- } \\
\text { portance of material posses- } \\
\text { sion in the life of a } \\
\text { person }\end{array}$ & $\begin{array}{l}\text { The enthusiasm of Japanese } \\
\text { millennials tofollow the } \\
\text { current trend }\end{array}$ \\
\hline $\begin{array}{l}\text { Consumer In- } \\
\text { novativeness }\end{array}$ & $\begin{array}{l}\text { The importance of buying } \\
\text { products }\end{array}$ & $\begin{array}{l}\text { The desire of Japanese mil- } \\
\text { lennials to buy Indonesian rat- } \\
\text { tan furniture in the future }\end{array}$ \\
\hline
\end{tabular}
Nostalgia The perception where things in The history between Indone- the past wereapparently better sia and Japan doesnot affect than the present Japanese millennials judge- ment toward Indonesian rattan furniture

Consumer The possession of a high sense For Japanese millennials, ratEthnocentrism of pride in the culture, symbols tan furniture does not have to and product themselves while come from Japan discrediting other cultures.

Environmen- The importance of consuming Environmental benefit of talism products withless pollution ef- Indonesian rattan furniture fects. is important to know for Japanese millennials

Source: edited by authors

\section{CONCLUSION}

The researcher summarized the data as follows, Japanese millennials possess only two out of five mentioned characteristics: intimacy (possess a close relationship with the high-technology product) and awareness (social responsibility). Whereas for loyalty, balanced and risk characteristics were not 
found in this research. For general values, the research findings reveal three value types that contribute to determining Japanese millennials' attitude toward Indonesian rattan furniture: hedonism, self-direction, and universalism. For consumer domain-specific values, the research findings contribute to determining Japanese millennials' attitude toward Indonesian rattan furniture, which are: Materialism, consumer innovativeness, nostalgia, consumer ethnocentrism, and environmentalism.

This research recommends that the subsequent research take a more extended period to provide further information. The subsequent research is recommended to take place in the South of Japan, for example, in Okinawa, where it is the best place for rattan products because of its warmer temperature than other places in Japan. The future researcher may collaborate with Japanese native speaker researchers to mitigate the cultural and language differences as the main barriers.

\section{REFERENCES}

Al Mamun, A. Mohamad, M.R. Bin Yaacob, M.R. \& Mohiuddin, M. 2018. Intention and behavior towards green consumption among low-income households. Journal of Environmental Management 227: 73-86.

Allen, J.C. \& Malin, S. 2008. Green Entrepreneurship: A Method for Managing Natural Resources? Society \& Natural Resources. An International Journal 21(9): 828-844.

Amoah, M. Dadzie, P.K. Bih, F.K. \& Wiafe, E.D. 2015. Consumer preferences and purchase intentions for rattan furniture. Wood and fiber science: journal of the Society of Wood Science and Technology 47(3): 225-239.

Bekaroo, G. Sungkur, R. Ramsamy, P. Okolo, A. \& Moedeen, W. 2018. Enhancing awareness on green consumption of electronic devices: The application of Augmented Reality. Sustainable Energy Technologies and Assessments, 30: 279-291.
Joshi, Y. \& Rahman, Z. 2016. Predictors of young consumer's green purchase behaviour. Management of Environmental Quality: An International Journal 27: 452-472.

Knight, D.K. \& Kim, E.Y. 2007. Japanese consumers need for uniqueness Effects on brand perceptions and purchase intention. Journal of Fashion Marketing and Management: An International Journal 270-280.

Lu, L. Bock, D. \& Joseph, M. 2013. Green marketing: what the Millennials buy. Journal of Business Strategy 34: 3-10.

Mason, J. 2002. Qualitative Researching. London: Sage Publications.

Ministry of Trade of The Republic of Indonesia. 2016. Market Brief: Tokyo Trade Attache Rattan Products. Retrieved from djpen.kemendag.go.id: http://djpen.kemendag.go.id/membership/data/file s/82e09-produk- rotan.pdf

Moreno, F.M. Lafuente, J.G. Carreón, F.Á. \& Moreno, S.M. 2017. The Characterization of the Millennials and Their Buying Behavior. International Journal of Marketing Studies (9): 135-144.

Myers, R. 2015. What the Indonesian rattan export ban means for domestic and international markets, forests, and the livelihoods of rattan collectors. Forest Policy and Economics 50: 210-219.

Pratono, A.H. Suyanto, Marciano, D. \& Zurbrügg, C. 2017. Social return on investment for communitybased enterprise in Surabaya City. The Hong Kong Journal of Social Work 51(1/2): 93-114.

Stanimir, A. 2015. Generation Y -Characteristics of Attitudes on Labour Market. Mediterranean Journal of Social Sciences 6: 22-28.

Steenkamp, J.B.E. \& de Jong, M.G. 2010. A Global Investigation into the Constelattion of Consumers Attitude Toward Global and Local Products. Journal of Marketing 74: 18-40.

Syrett, M. \& Lammiman, J. 2004. Advertising and Millennials. Young Consumers 5: 62-73.

Veleva, V. \& Ellenbecker, M. 2001. Indicators of sustainable production: framework and methodology. Journal of Cleaner Production 9(6): 519549.

Widayati, A. \& Carlisle, B. 2012. Impacts of rattan cane harvesting on vegetation structure and tree diversity of Conservation Forest in Buton, Indonesia. Forest Ecology and Management 266: 206215.

Wong, S.K.S. 2012. The influence of green product competitiveness on the success of green product innovation. European Journal of Innovation Management 15(4): 468-490. 